\title{
Perceived Barriers to Weight Management in Primary Care-Perspectives of Patients and Providers
}

\author{
Alicia R. Ruelaz, $M D^{7}$, Pamela Diefenbach, $M D^{2}$, Barbara Simon, $M A^{3}$, Andy Lanto, $M A^{3}$, \\ David Arterburn, MD, MPH ${ }^{4}$, and Paul G. Shekelle, MD, $P h D^{2,3}$
}

${ }^{1}$ Cedars-Sinai Medical Center, MD-8700 Beverly Boulevard, 8th floor, Room 8631, Los Angeles, CA 90048, USA; 'reater Los Angeles Veteran's Administration Healthcare System, Los Angeles, CA, USA; ${ }^{3}$ VA Health Services Research and Development Center of Excellence for the Study of Provider Behavior, Los Angeles, CA, USA; ${ }^{4}$ Group Health Center for Health Studies, Seattle, WA, USA.

BACKGROUND: Despite the consequences of overweight and obesity, effective weight management is not occurring in primary care.

OBJECTIVE: To identify beliefs about obesity that act as barriers to weight management in primary care by surveying both patients and providers and comparing their responses.

DESIGN: Anonymous, cross-sectional, self-administered survey of patients and providers of a Veteran's Administration Primary Care Clinic, distributed at the clinic site.

SUBJECTS: Forty-eight Internal Medicine providers and 488 patients.

MEASUREMENTS: Beliefs, attitudes, and experiences with weight management as well as demographic characteristics were collected through a questionnaire.

RESULTS: Providers and patients differed significantly on many beliefs about weight. Providers were more likely than patients to perceive that patients lack selfcontrol to stay on a diet and that fattening food in society and lack of time for exercise were prime factors in weight gain. They also expressed more interest in helping patients with weight management than patients desiring this. Patients were more likely to state that weight problems should be managed on one's own, talking to a provider is not helpful, providers blame them for their weight problem, and that appointments contain sufficient time for weight discussion.

CONCLUSION: Providers and patients emphasize different barriers to weight management. Providers need to be aware of the beliefs that their patients hold to improve weight management discussions and interventions in primary care.

KEY WORDS: weight management; primary care; attitudes; beliefs; barriers.

DOI: $10.1007 / \mathrm{s} 11606-007-0125-4$

() 2007 Society of General Internal Medicine 2007;22:518-522

\section{INTRODUCTION}

Obesity is one of the fastest-growing health problems in the United States. Currently, approximately $64 \%$ of the adult population is either overweight or obese defined as a body mass index $(\mathrm{BMI}) \geq 25 \mathrm{~kg} / \mathrm{m}^{2}{ }^{1}$ Within the Veteran's Administration specifically, $73 \%$ of male veterans are overweight and $33 \%$ are obese. ${ }^{2}$

Analyzing data from the 1996 Behavioral Risk Factor Surveillance System, we found out that, when advised to lose weight by a physician, $78 \%$ of overweight patients reported attempting to lose weight. ${ }^{3}$ However, if their physician did not discuss weight loss with them, only $33 \%$ of patients within the same BMI category attempted to do so. Despite these compelling data, only $9.8 \%$ of all patients reported receiving any advice from a physician to lose weight. ${ }^{4}$ A recent study of 424 patient charts of Veteran's Administration (VA) Internal Medicine residents found that only $7.3 \%$ of their overweight patients and $30.9 \%$ of their obese patients were identified as such and only $16.5 \%$ of those patients received any form of weight management. ${ }^{5}$

If advising their patients to lose weight can be such an effective motivator, why aren't more physicians doing so? Previous studies had found that physicians held negative views regarding their ability to manage weight in primary care as well as stereotypical views toward obese patients in general. $^{6-8}$ Patient studies found lack of willpower and time constraints as barriers. ${ }^{9}$ Because studies of patients and physicians' perspectives have assessed only one of these groups at a time, it leaves unanswered the question whether differences in perspectives compared across studies are because of true differences in attitudes between patients and physicians or because of other differences (location, time, etc.) between the populations studied. Thus, we sought to understand the potential reasons for poor attention to weight management in the primary care clinic by assessing physicians and patients' beliefs and attitudes regarding potential barriers to weight management.

\section{METHODS}

This was a cross-sectional study of patients and providers in the primary care clinic of the West Los Angeles Veteran's Administration Medical Center. This primary care clinic serves a diverse population of 13,086 veterans. Care is provided by Internal Medicine attending staff physicians, Internal Medicine
Received July 3, 2006

Revised October 25, 2006

Accepted January 8, 2007

Published online January 30, 2007 
house staff supervised by attendants, nurse practitioners, and physician assistants.

This study was approved by the Greater Los Angeles Veteran's Administration Medical Center Institutional Review Board.

\section{Patient Survey}

During the week of March 7-11, 2005, patients presenting for their regularly scheduled appointments in the primary care clinic were offered a "Veteran Survey of Weight Management" when they checked in. Surveys were completed anonymously and placed in a box in the waiting room.

\section{Provider Survey}

The providers of the primary care clinic were given surveys during their regularly scheduled administrative meetings and they placed them in a box in their conference room.

The surveys collected data on age, gender, race/ethnicity, and highest level of education completed. The survey also asked participants to report their current height and weight, which was used to calculate BMI. Based on the National Institute of Health definitions of overweight and obesity, patient survey respondents were divided into one of two categories: those who are considered overweight or obese $(\mathrm{BMI} \geq 25)$, and those with normal or lower than normal body weight $(\mathrm{BMI}<25)$. For these analyses, we chose to focus on the responses from patients that were overweight and obese as this population is broadly recognized as needing active weight loss treatment.
Additional survey questions were designed to measure beliefs and attitudes of the patients and providers in various domains. These domains included the attitudes toward and beliefs about overweight and obese individuals, beliefs about the etiology of overweight and obesity, attitudes toward and beliefs about weight management in the primary care clinic, beliefs about the patients of the primary care clinic, and beliefs about the providers of the primary care clinic. Many of these questions were drawn from previously published studies of overweight and obese adults. Such statements included that patients were lazy or lacked self-control, ${ }^{7}$ patients lack willpower and do not have time for diet and exercise, ${ }^{9}$ and counseling is futile and counseling patients would take too much time. ${ }^{6}$ Patients were asked if they strongly agree, agree, neither agree nor disagree, disagree, or strongly disagree to the statements that are presented in Table 2. The full surveys are available online.

\section{Statistical Analysis}

Our primary research questions concerned comparing the attitudes and beliefs of obese and overweight patients with their providers. For data analyses, the strongly agree and agree responses were combined into an agree category whereas those responding neither agree nor disagree, disagree, or strongly disagree comprised the does not agree category. We performed a sensitivity analysis that removed the neither agree nor disagree responses from our comparisons. These results upheld our primary analysis, so only the primary analysis is presented in this report. Statistical analyses evaluating these perceived barriers to weight management between overweight

Table 1. Characteristics of Survey Respondents, Primary Care Clinic Population, and VA Providers

\begin{tabular}{|c|c|c|c|c|c|c|}
\hline & $\begin{array}{l}\text { Survey respondents, } \\
N=435\end{array}$ & Percent & $\begin{array}{l}\text { Primary care clinic } \\
\text { population, } N=12,290\end{array}$ & Percent & $\begin{array}{l}\text { VA providers, } \\
N=48\end{array}$ & Percent \\
\hline \multicolumn{7}{|l|}{ Gender } \\
\hline Male & 424 & 97.5 & & & 28 & 58.3 \\
\hline Female & 11 & 2.5 & & & 19 & 39.6 \\
\hline \multicolumn{7}{|l|}{ Age } \\
\hline$<35$ & 25 & 5.8 & 561 & 5 & 26 & 54 \\
\hline $36-45$ & 25 & 5.8 & 757 & 6 & 7 & 14.6 \\
\hline $46-55$ & 82 & 19.0 & 2,082 & 17 & 7 & 15 \\
\hline $56-65$ & 129 & 29.9 & 3,496 & 28 & 4 & 8 \\
\hline$>65$ & 179 & 39.5 & 5,394 & 44 & 2 & 4 \\
\hline \multicolumn{7}{|l|}{ Race } \\
\hline White & 213 & 49.3 & 2,505 & 20 & 24 & 50 \\
\hline African-American & 149 & 34.5 & 2,345 & 19 & 0 & 0 \\
\hline Hispanic & 37 & 8.6 & 331 & 3 & 2 & 4 \\
\hline Other & 33 & 7.6 & 881 & 7 & 20 & 42 \\
\hline Not reported & & & 6,137 & 50 & 2 & 4 \\
\hline \multicolumn{7}{|l|}{ Obesity-related comorbidity } \\
\hline Arthritis & 143 & 33.5 & 986 & 8 & & \\
\hline Diabetes & 118 & 27.7 & 2,957 & 24 & & \\
\hline Heart disease & 104 & 24.4 & 3,309 & 27 & & \\
\hline High blood pressure & 285 & 66.7 & 6,998 & 57 & & \\
\hline High cholesterol & 211 & 49.8 & 6,982 & 57 & & \\
\hline Sleep apnea & 69 & 6.2 & 1,734 & 14 & & \\
\hline \multicolumn{7}{|l|}{ Education } \\
\hline$<$ High school graduate & 32 & 7.4 & & & 8 & 16.7 \\
\hline High school graduate & 403 & 92.7 & & & 13 & 27.1 \\
\hline Trade school & 34 & 7.8 & & & 17 & 35.4 \\
\hline College graduate & 113 & 26.0 & & & 8 & 16.7 \\
\hline Postgraduate degree & 42 & 9.7 & & & 2 & 4.2 \\
\hline
\end{tabular}


and obese patients, as well as primary care providers were conducted using a series of $2 \times 2$ chi-square tests.

\section{RESULTS}

\section{Patient and Provider Characteristics}

During the week of the study, 488 patients completed and returned surveys. Of the surveys collected, 53 had unusable data because of inadequate or nonresponse to key questions and these were therefore excluded from our analyses. Of the remaining 435 patients, 329 were classified as overweight (BMI 25-29.99) or obese (BMI 30+). Calculating a response rate was problematic. We knew that 1,054 patients were scheduled for appointments during that week and we also know that not all patients were offered the opportunity to complete the survey (because of time constraints, inattention by the front desk clerk, and other factors). However, we do not know how many patients were offered the survey. Importantly, the population in which we intended our findings to be applicable to is not the patients who attended the clinic that week, but rather the patients of the General Medical Clinic as a whole. During the 1-year period from September 1, 2004 until August 31, 2005 that included the study period, 12,290 patients visited the primary care clinic. The demographic characteristics of this VA primary care clinic are also shown in Table 1. Overall, the characteristics of the patients in our study sample are very similar to the characteristics of that general clinic population in age, gender, and health conditions. However, our study participants reported hypertension $(11 \%)$ and arthritis $(25 \%)$ more often than the general clinical population.

Of the 50 providers offered to take survey, 48 completed and turned it in, giving a 96\% response rate. Demographic characteristics of providers are also presented in Table 1.

\section{Perceived Barriers to Weight Management}

Table 2 displays the survey statements that represent different areas in which barriers to weight management are perceived. The patients and providers surveyed displayed some areas of agreement. For example, very few patients and providers reported that providers were less friendly to overweight people or that they were embarrassed to talk about weight problems. Most patients and providers agreed that useful dieting tips can be exchanged in the primary care setting, overweight people could control their weight if they exercised more, and overweight people who lose weight usually gain it back.

Patients and providers disagreed in two key areas: beliefs about the etiology of weight problems and the role the medical system should play in weight management. Providers were more likely than their overweight patients to believe that patients lack the self-control to stay on a diet. Providers were also more likely to agree with the statement that people gain weight because of the availability of fattening food in our society and because finding time for physical activity is too hard. With regard to the role of health care in weight management, providers reported a higher level of interest in helping patients manage their weight than patients wanting their provider involved.

Patients were more likely than providers to agree that people with weight problems should manage them on their own and that talking to a primary care provider would not be helpful. Patients were also more likely to feel their providers were blaming them for their weight problems whereas providers did not report this as an issue. Finally, providers reported not having enough time to discuss weight management during a routine primary care appointment whereas patients felt there is enough time.

\section{DISCUSSION}

By comparing the responses of overweight and obese patients to the responses of the primary care providers, we found significant differences in the extent to which providers and patients endorse questions about barriers to weight management. We also observed that patients and providers shared some important, but incorrect, beliefs about weight management.

Regarding the latter, more than $40 \%$ of patients and providers believed that some people cannot lose weight no matter how little they eat. Research has shown that patients sometimes underestimate how much they eat. ${ }^{10,11}$ Similarly, $70 \%$ of patients and $84 \%$ of providers believed that some medical conditions made people gain weight or unable to lose weight. Research has shown that medical conditions causing obesity are either rare or account for only modest weight gain seen in those patients. ${ }^{12}$ However, this question was worded so broadly that it could include persons with osteoarthritis (which limits physical activity) or use of drugs that cause weight gain (such as olanzapine), and this belief should be examined more precisely in future surveys. It was also surprising that nearly half of these obese and overweight patients believed they could lose weight "when I need to," which may highlight the need for providers to motivate these patients.

Regarding differences between groups, we saw that providers were more likely to perceive that factors outside of the provider's control, such as lack of patient self-control, the availability of fattening food in our society, and the lack of time for exercise were responsible for the weight problems of their patients. They expressed interest in helping patients manage weight but identified lack of time during routine primary care appointments as a barrier to this vehicle of weight management.

Previous studies had shown that there was an inadequate amount of weight management occurring within the primary care clinic. ${ }^{4,5}$ Our study suggests a possible reason for this is providers perceived futility based on how they view their patients' ability to lose weight as well as environmental factors beyond their control.

It is also important for providers to be aware that their patients are less likely to turn to their providers for help and therefore discussions of weight must be initiated by the provider. As noted in previous studies, patients in our study were less likely than the providers to look to the primary care clinic as a resource for weight management, going so far as to say that overweight people should manage weight on their own and that talking to a provider would not be helpful. ${ }^{9}$ Despite this, those patients surveyed within the Behavioral Risk Factor Surveillance System whose physicians talked to them about weight did show higher levels of attempts to lose weight. ${ }^{4}$ This indicates the need for physicians to initiate these discussions 
Table 2. Proportion and Number of Patients and Providers Who Agree or Strongly Agree with Each Survey Statement

\begin{tabular}{|c|c|c|c|c|}
\hline Patient survey questions & Provider survey questions & Patient & Provider & $P$ value \\
\hline $\begin{array}{l}\text { I feel comfortable talking to my VA primary care providers } \\
\text { about my weight. }\end{array}$ & $\begin{array}{l}\text { I feel comfortable talking to my patients about their } \\
\text { weight }\end{array}$ & $\begin{array}{l}0.88 \\
(316)\end{array}$ & $\begin{array}{r}0.94 \\
(48)\end{array}$ & 0.26 \\
\hline $\begin{array}{l}\text { My VA primary care providers would blame me if I had a } \\
\text { weight problem. }\end{array}$ & $\begin{array}{l}\text { If I talk to patients about their weight, most would feel } \\
\text { I'm blaming them for their weight problem }\end{array}$ & $\begin{array}{l}0.26 \\
(302)^{*}\end{array}$ & $\begin{array}{r}0.10 \\
(48)\end{array}$ & 0.02 \\
\hline $\begin{array}{l}\text { There is usually enough time during a visit for my VA } \\
\text { primary care provider to discuss weight with me. }\end{array}$ & $\begin{array}{l}\text { There is usually enough time during a routine } \\
\text { appointment to discuss weight with my patients }\end{array}$ & $\begin{array}{l}0.73 \\
(309)^{*}\end{array}$ & $\begin{array}{r}0.40 \\
(48)\end{array}$ & $<0.01$ \\
\hline $\begin{array}{l}\text { I don't think talking to a VA primary care provider about } \\
\text { my weight would be helpful. }\end{array}$ & $\begin{array}{l}\text { I don't think talking to my patients about their weight } \\
\text { would be helpful }\end{array}$ & $\begin{array}{l}0.22 \\
(307)^{*}\end{array}$ & $\begin{array}{r}0.06 \\
(48)\end{array}$ & 0.01 \\
\hline $\begin{array}{l}\text { I can get useful tips on dieting from my VA primary care } \\
\text { provider. }\end{array}$ & I can provide useful tips on dieting to my patients & $\begin{array}{l}0.67 \\
(308)\end{array}$ & $\begin{array}{r}0.77 \\
(48)\end{array}$ & 0.15 \\
\hline $\begin{array}{l}\text { I am embarrassed to talk about my weight with my VA } \\
\text { primary care provider. }\end{array}$ & $\begin{array}{l}\text { I feel my patients are too embarrassed to talk about their } \\
\text { weight problems with me }\end{array}$ & $\begin{array}{l}0.09 \\
(309)\end{array}$ & $\begin{array}{r}0.08 \\
(48)\end{array}$ & 0.82 \\
\hline $\begin{array}{l}\text { I would like my VA primary care providers to be more } \\
\text { involved in helping me to manage my weight. }\end{array}$ & $\begin{array}{l}\text { I would like to be more involved in helping my patients } \\
\text { manage their weight }\end{array}$ & $\begin{array}{l}0.44 \\
(308)^{*}\end{array}$ & $\begin{array}{r}0.67 \\
(48)\end{array}$ & $<0.01$ \\
\hline $\begin{array}{l}\text { Overweight people lack willpower compared to normal } \\
\text { weight people. }\end{array}$ & $\begin{array}{l}\text { Overweight people lack willpower compared to normal } \\
\text { weight people. }\end{array}$ & $\begin{array}{l}0.38 \\
(314)\end{array}$ & $\begin{array}{r}0.35 \\
(48)\end{array}$ & 0.74 \\
\hline $\begin{array}{l}\text { Overweight people are lazier than people of normal } \\
\text { weight. }\end{array}$ & $\begin{array}{l}\text { Overweight people are lazier than people of normal } \\
\text { weight. }\end{array}$ & $\begin{array}{l}0.24 \\
(312)\end{array}$ & $\begin{array}{r}0.17 \\
(48)\end{array}$ & 0.26 \\
\hline $\begin{array}{l}\text { People who are overweight could control their weight } \\
\text { if they exercised more. }\end{array}$ & $\begin{array}{l}\text { People who are overweight could control their weight if } \\
\text { they exercised more. }\end{array}$ & $\begin{array}{l}0.73 \\
(313)\end{array}$ & $\begin{array}{r}0.79 \\
(48)\end{array}$ & 0.38 \\
\hline Most people’s overweight problems are inherited. & Most people’s overweight problems are inherited. & $\begin{array}{l}0.18 \\
(306)\end{array}$ & $\begin{array}{r}0.25 \\
(48)\end{array}$ & 0.28 \\
\hline $\begin{array}{l}\text { Some people no matter how little they eat cannot lose } \\
\text { weight. }\end{array}$ & $\begin{array}{l}\text { Some people no matter how little they eat cannot lose } \\
\text { weight. }\end{array}$ & $\begin{array}{l}0.43 \\
(314)\end{array}$ & $\begin{array}{c}0.41 \\
(46)\end{array}$ & 0.86 \\
\hline $\begin{array}{l}\text { Overweight people who lose weight usually gain the } \\
\text { weight back. }\end{array}$ & $\begin{array}{l}\text { Overweight people who lose weight usually gain the } \\
\text { weight back. }\end{array}$ & $\begin{array}{l}0.68 \\
(315)\end{array}$ & $\begin{array}{r}0.72 \\
(47)\end{array}$ & 0.52 \\
\hline $\begin{array}{l}\text { People gain weight because fattening food is too available } \\
\text { in our society. }\end{array}$ & $\begin{array}{l}\text { People gain weight because fattening food is too available } \\
\text { in our society. }\end{array}$ & $\begin{array}{l}0.73 \\
(313)^{*}\end{array}$ & $\begin{array}{r}0.92 \\
(48)\end{array}$ & $<0.01$ \\
\hline $\begin{array}{l}\text { People gain weight because fitting physical activity into } \\
\text { one's day is too hard. }\end{array}$ & $\begin{array}{l}\text { People gain weight because fitting physical activity into } \\
\text { one's day is too hard. }\end{array}$ & $\begin{array}{l}0.45 \\
(311)^{*}\end{array}$ & $\begin{array}{r}0.75 \\
(48)\end{array}$ & $<0.01$ \\
\hline $\begin{array}{l}\text { People with weight problems should manage their weight } \\
\text { on their own }\end{array}$ & $\begin{array}{l}\text { People with weight problems should manage their weight } \\
\text { on their own }\end{array}$ & $\begin{array}{l}0.27 \\
(315)^{*}\end{array}$ & $\begin{array}{r}0.10 \\
(48)\end{array}$ & 0.01 \\
\hline $\begin{array}{l}\text { Some medical conditions make people gain weight or } \\
\text { make them unable to lose weight. }\end{array}$ & $\begin{array}{l}\text { Some medical conditions make people gain weight or } \\
\text { make them unable to lose weight. }\end{array}$ & $\begin{array}{l}0.70 \\
(314)\end{array}$ & $\begin{array}{r}0.83 \\
(48)\end{array}$ & 0.06 \\
\hline There is no truly effective treatment for obesity. & There is no truly effective treatment for obesity. & $\begin{array}{l}0.11 \\
(314)^{*}\end{array}$ & $\begin{array}{c}0.21 \\
(47)\end{array}$ & 0.05 \\
\hline $\begin{array}{l}\text { Doctors are less friendly to overweight people than to } \\
\text { people of normal weight. }\end{array}$ & $\begin{array}{l}\text { You are less friendly to overweight patients than to } \\
\text { patients of normal weight }\end{array}$ & $\begin{array}{l}0.07 \\
(313)\end{array}$ & $\begin{array}{r}0.04 \\
(48)\end{array}$ & 0.46 \\
\hline I don't think I have the self-control to stay on a diet. & $\begin{array}{l}\text { Most primary care patients lack enough self-control to } \\
\text { stay on a weight loss diet }\end{array}$ & $\begin{array}{l}0.22 \\
(318)^{*}\end{array}$ & $\begin{array}{r}0.46 \\
(48)\end{array}$ & $<0.01$ \\
\hline I have no motivation to lose weight. & $\begin{array}{l}\text { Most primary care patients who need to lose weight have } \\
\text { no motivation to diet }\end{array}$ & $\begin{array}{l}0.16 \\
(315)^{*}\end{array}$ & $\begin{array}{c}0.44 \\
(48)\end{array}$ & $<0.01$ \\
\hline I can lose weight when I need to. & $\begin{array}{l}\text { Most primary care patients can lose weight when they } \\
\text { need to }\end{array}$ & $\begin{array}{l}0.49 \\
(314)^{*}\end{array}$ & $\begin{array}{r}0.29 \\
(48)\end{array}$ & $<0.01$ \\
\hline
\end{tabular}

as patients may not recognize the primary care provider as a possible weight management resource.

To address the issue of provider perception of inadequate time, brief weight management interventions have been devised to fit within the 10- to 15-minute time frame allotted for most primary care appointments. ${ }^{13}$

\section{Limitations}

The primary limitation of this study is that we used an opportunistic rather than a random sample of primary care attendees. We made this choice because with an anonymous survey we sought to minimize the possibility that participants would answer questions about their experiences in a socially expected fashion. The generalizability of our results therefore rests on the degree to which patients completing our survey are similar to the general clinic population. Using information routinely collected by the VA, our study population closely mirrored the general clinic population on most demographic parameters, although race cannot be compared as it is not routinely collected by the VA.

\section{Conclusions}

In conclusion, we found that primary care providers and their overweight patients differ on some perceived barriers to weight management within the primary care clinic. Because providers talking to their patients about weight has been shown to lead to patients attempting to lose weight, interventions aimed at reinforcing to physicians the effectiveness of weight control counseling may lead to greater awareness and action with these overweight patients.

Acknowledgement: This study was supported by the Veteran's Administration Health Services Research and Development Center of Excellence for the Study of Provider Behavior, who provided methodologic and statistical support and coauthored the report. Dr. Ruelaz conducted this study as part of a psychosomatic medicine fellowship. 
Potential Financial Conflicts of Interest: None disclosed

Corresponding Author: Alicia R. Ruelaz, MD; Cedars-Sinai Medical Center, MD-8700 Beverly Boulevard, 8th floor, Room 8631, Los Angeles, CA 90048, USA (e-mail: ruelaza@cshs.org).

\section{REFERENCES}

1. Ogden CL, Carroll MD, Curtin LR, McDowell MA, Tabak CJ, Flegal KM. Prevalence of overweight and obesity in the United States, 19992004. JAMA. 2006;295:1549-55.

2. Das SR, Kinsinger LS, Yancy WS Jr, et al. Obesity prevalence among veterans at Veterans Affairs medical facilities. Am J Prev Med. 2005;28:291-4.

3. Stafford RS, Farhat JH, Misra B, Schoenfeld DA. National patterns of physician activities related to obesity management. Arch Fam Med. 2000;9:631-8.

4. Sciamanna CN, Tate DF, Lang w, Wing RR. Who reports receiving advice to lose weight? Results from a multistate survey. Arch Intern Med. 2000;160:2334-9.

5. Ruser CB, Sanders L, Brescia GR, et al. Identification and management of overweight and obesity by internal medicine residents. J Gen Intern Med. 2005;20:1139-41.
6. American Medical Association, Robert Wood Johnson Foundation Assessment and Management of Adult Obesity_A Primer for Physicians, Booklet 1. American Medical Association Roadmaps for Clinical Practice: Robert Wood Johnson Foundation; 2003:iii, 10.

7. Price JH, Desmond SM, Krol RA, Snyder FF, O'Connell JK. Family practice physicians' beliefs, attitudes, and practices regarding obesity. Am J Prev Med. 1987;3:339-45.

8. Harris SB, Petrella RJ, Lambert-Lanning A, Leadbetter W, Cranston L. Lifestyle management for type 2 diabetes. Are family physicians ready and willing? Can Fam Physician. 2004;50:1235-43.

9. Johnson CA, Corrigan SA, Dubbert PM, Gramling SE. Perceived barriers to exercise and weight control practices in community women. Women Health. 1990;16:177-91.

10. Pikholz C, Swinburn B, Metcalf P. Under-reporting of energy intake in the 1997 National Nutrition Survey. N Z Med J. 2004;117(1202): U1079.

11. Poppitt SD, Swann D, Black AE, Prentice AM. Assessment of selective under-reporting of food intake by both obese and non-obese women in a metabolic facility. Int J Obes Relat Metab Disord. 1998;22 (4):303-11.

12. Bray, George. Etiology and natural history of obesity. UpToDate February 17, 2006.

13. Wadden TA, Berkowitz RI, Womble LG, et al. Randomized trial of lifestyle modification and pharmacotherapy for obesity. N Engl J Med. 2005;353:2111-20. 